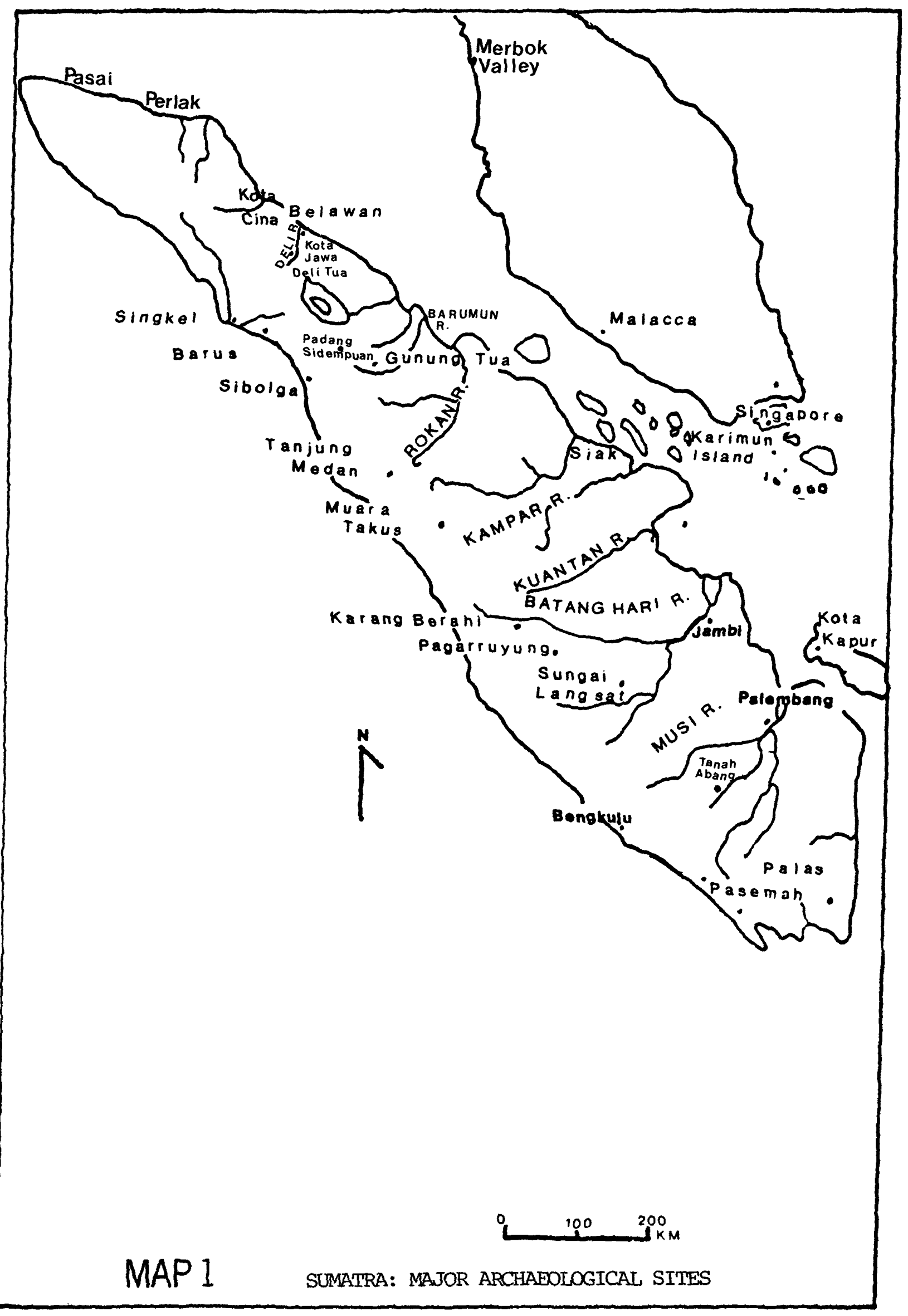




\title{
CLASSICAL ARCHAEOLOGY IN SUMATRA
}

\author{
John Miksic
}

Eventually archaeology is likely to provide the most fruitful indigenous data for understanding Sumatra's societies during the "Classical" period, I but its potential for disclosing Sumatra's past has as yet hardly been tapped. In this article, after summarizing the information that can be gained from a study of the island's geography and the writings of travelers to the region, I will make a brief survey of the major archaeological sites, and attempt to assess the current status of archaeological studies on Sumatra. From this it will become clear how random and restricted our present knowledge is, and how enormous are the regions to be explored before locally obtained information on Sumatra's early economic and political conditions outweighs that available from foreign sources.

A systematic survey of Sumatran archaeological resources has been underway for about ten years, with the Indonesian National Research Centre for Archaeology (Pusat Penelitian Purbakala dan Peninggalan Nasional or Pusat P 3N) having conducted a number of expeditions to various parts of the island and issued subsequent reports. It is, however, likely that we will have to wait many more years before data collected from sites distributed throughout the island becomes sufficient for us to reconstruct early political, economic, and social processes in Sumatra. Only with such a well-distributed body of data can we expect to detect meaningful patterns in the locations and artifactual inventories of sites, and from these patterns create integrated reconstructions of the island during different periods, recovering links between its various regions, and measuring objectively the influences exerted on Sumatran life by outside forces.

It has recently been argued that "ancient riverine experience in mobilizing neighborhoods .. rather than maritime or commercial acumen first stood the rulers in good stead when they began to participate in foreign trading enterprise and developed entrepot pretensions." ${ }^{2}$ If this is true, we are faced with the task of discovering clues to the social bonds that rulers were able to manipulate in order to mobilize manpower as well as materials for subsistence and commerce. This statement also implies, as does the story of the founding of the first Malay kingdom in Sumatra in the Sejarah Melayu, that any study of the evolution of Sumatra's classi-

1. In Indonesia the word "Classic" (Kelasik) is commonly used to refer to the period beginning in about the fourth century AD when Indian-influenced art styles and writing first appear, and ending in the sixteenth century with the conversion of much of Sumatra and Java to Islam. The Indonesian National Research Centre for Archaeology contains a "Classical Section" (Bidang Kelasik). Although a system of nomenclature for Indonesia's past which used indigenous terminology would perhaps be more appropriate, there is no such commonly accepted periodization either in historical or archaeological circles.

2. O. W. Wolters, "Studying Srivijaya," Journal of the Malaysian Branch of the Royal Asiatic Society [henceforth JMBRAS] , 52, 2 (1979), p. 29. 
cal trading kingdoms should begin in the hinterland, rather than in the coastal lowlands where they reached their apex of fame and wealth. One promising region is the Pasemah highlands, at the foot of Gunung Dempo, which are drained by two tributaries of the Musi River, the Ogan and the Lematang. Scattered about these highlands are numerous boulders carved in relief, as well as stone alignments, tombs constructed of large rock slabs, and other remains which offer evidence of a preclassic culture which possessed both a unique art style and probably also a capacity for bronze working, utilizing motifs from other parts of Southeast Asia. ${ }^{3}$ Unfortunately, neither available archaeological data nor historical sources allow us as yet to determine whether the first steps toward development of a political organization sophisticated enough to mobilize manpower and resources on a large scale took place in this or another highland center or centers, and whether these later came under the ascendancy of coastal or estuarine centers more favorably situated to control commercial relations with foreign groups.

This example should demonstrate that the search for ways to reconstruct mobilization networks should take into account not only artifacts but also the geographical relationship of archaeological sites to traditional communication and transport routes, and to zones capable of producing foodstuffs and locally consumed commodities as well as exportable merchandise. These natural factors provide a context within which we can begin to make sense of sites already discovered and relate them to information available from historical sources.

The geography of Sumatra therefore is very important in retracing the evolution of its civilization. Sumatra is the world's sixth largest island, approximately two thousand kilometers in length, oriented approximately NNW-SSE, and it sits almost precisely astride the equator. The Barisan mountain range runs all down the western side of the island, with peaks up to four thousand meters' elevation. The watershed between east- and west-flowing rivers is seldom more than fifty kilometers from the west coast. The island's population is now about twenty million. The densest concentrations of rural population are found principally on the fertile volcanic plateaus of west Sumatra and the alluvium of coastal Aceh. ${ }^{4}$ The eastern coastal plain occupies 50 percent of the island, or 120,000 square kilometers, and is in general the least densely populated zone, with fewer than sixteen people per square kilometer.

The coastal plain is largely made up of sediments deposited by the great rivers which flow eastward from the Barisan Mountains to the Straits of Malacca. This deposition process continues today, and the shallowness of the sea covering the Sunda Shelf combines with such other factors as forest cutting, heavy rainfall, and tectonic movements to make the location of the coastline a constantly and rapidly changing phenomenon in certain areas. The very low elevation of much of the land means that the boundary between land and water is seldom clear even at some distance from the rivers or open sea.

3. A. N. J. T. à T. van der Hoop, Megalithic Remains in South-Sumatra (Zutphen: Thieme, 1933); H. R. van Heekeren, The Bronze-Iron Age of Indonesia (The Hague: Nijhoff, 1958). F. D. K. Bosch described a bronze "flask" from the central highland area of Kerinci, which possesses no Hindu motifs but displays Dongsonian affinities, and may have been made locally; "Aanwinsten van de archaeologische collectie van het Bataviaasch Genootschap," Oudheidkundig Verslag [henceforth OV] (1922), pp. 65-66.

4. W. A . Withington, "The Distribution of Population in Sumatra, Indonesia, 1961," Malayan Journal of Tropical Geography, 17 (1963), pp. 203-12. 
In the lowland portions of their courses the rivers are tidal for great distances upstream, and deep enough for ocean-going ships to sail far inland. The port of Jambi is one hundred kilometers up the Batang Hari, and, in 1920, Palembang, ninety kilometers up the Musi, could be visited by ships with twenty feet draft. ${ }^{5}$

The plain began to emerge from the coastal shallows at least five thousand years ago, perhaps even earlier. Several scholars have attempted to reconstruct Sumatran coastlines of the classical period, ${ }^{6}$ but their studies have been based on projections of present rates of change into the past rather than on studies of the soils of various localities, and they are thus unreliable in their details. ${ }^{7}$ Nevertheless, it is likely that five thousand years ago several large bays or estuaries indented the east coast; these estuaries gradually became constricted by sediment deposited by the rivers flowing into them, and by ocean currents removing material from one shoreline and redepositing it on another, so that the relatively even coastline now in existence was created. 8

Legends of coastal change are common in Sumatran folklore. ${ }^{9}$ Scientific examination and measurement of the process, however, have only recently begun, and many factors have to be taken into account; so there are as yet no firm data on which to base an interpretation of lowland Sumatran sites in terms of their location relative to coast and hinterland. Radiocarbon dates recently obtained indicate that coastal change may not have been as rapid an occurrence as previously believed, at least in the northeastern area. ${ }^{10}$

5. C. Lekkerkerker, Land en Volk van Sumatra (Leiden: Brill, 1916), p. 9; Nederlandsche Indische Havens, Mededeeling en Rapporten, Havenwezen no. 5 (Batavia: Departement der Burgerlijke Openbare Werken, 1920), p. 117.

6. V. Obdeijn, "Zuid-Sumatra volgens de oudste berichten. I. De geomorfologische gesteldheid van Zuid-Sumatra in verband met de opvatting der ouden," Tijdschrift van het Koninklijke Nederlands Aardrijkskundige Genootschap (henceforth TNAG), 58 (1941), pp. 190-217; R. Soekmono, "Geomorphology and the Location of Srivijaya," Madjalah IImu-llmu Sastra Indonesia, 1, 1 (1963), pp. 78-90.

7. J. Miksic, "Archaeology and Palaeogeography in the Straits of Malacca," in Economic Exchange and Social Interaction in Southeast Asia, ed. K. Hutterer, Michigan Papers on South and Southeast Asia, no. 13 (1977), pp. 155-75.

8. M. J. H. Chambers and A. Sobur, "The Rates and Processes of Recent Coastal Accretion in the Province of South Sumatra: A Preliminary Survey" (Paper presented at the Regional Conference on the Geology and Mineral Resources of South East Asia, Jakarta, 1975).

9. Obdeijn, "Zuid-Sumatra," pp. 190, 214; W. Marsden, History of Sumatra (1811; reprint ed., Kuala Lumpur: Oxford University Press, 1966), p. 359; J. Anderson, Mission to the East Coast of Sumatra in 1823 (1826; reprint ed., Kuala Lumpur: Oxford University Press, 1971), pp. 32, 197.

10. A sample of mangrove wood from a test pit in the village of Sukajadi gave a C-14 date of $5055 \pm 65$ years BP [Before Present] (Smithsonian Institution Radiation Biology Laboratory no. SI-4031). This date is consistent with the association between the mangrove sample tested and a shell midden containing burials and stone tools related to the "Hoabinhian" type. E. E. McKinnon, "A Brief Note on the Current State of Certain of the Kitchen Middens of East Sumatra," Berita Kajian Sumatera (henceforth $B K S), 4,2(1975), \mathrm{pp} .45-50$. The site is now approximately fifteen kilometers from the coast. On the basis of historical evidence and personal observation, Professor Wolters believes that the rate of recent coastal change in the lower Musi may also have been more gradual than other scholars have 
The lowlands between the river courses are mainly composed of peaty soil which needs heavy liming to counteract its acidity if it is to support most crops. ${ }^{11}$ Alluvial soil suitable for wet rice occurs mainly near river courses, including those which have become silted in. The place-name "Sungai Mati" (Dead River) occurs a number of times in the lowlands, suggesting that the death of a river is recorded in local memory. The fertility of the soil varies from valley to valley, depending upon the differences between parent materials in the rivers' headwaters from which the sedimentary deposits derive. ${ }^{12}$

The areas now most intensively cultivated are shown on Map 2. Of these, the Batang Hari valley in Jambi, the upper reaches of the Musi and its tributaries, and the coastal strip in north Aceh are soils deposited by flowing water. Men have also long exploited a second type of soil found on high plateaus and composed of volcanic materials weathered from the rocks in situ. This type is found in the Pasemah highlands in the south, the Padang highlands in the west central region, and the Karo Plateau in the northeast.

Another factor to be taken into account when searching for a pattern in the geographical dispersal of classic Sumatran sites is the distribution of the mineral, vegetable, and animal resources that were important in long-distance trade between Sumatra and China, India, and western Asia. The island's mineral resources (see Map 2) included gold, which was mined, perhaps in large quantities, by the Sumatrans before the sixteenth century (and which they also extracted from alluvial deposits by the placer method), as well as silver, lead, copper, zinc, iron, and mercury. The largest pre-European mine-workings were probably in the RejangLebong area of Bengkulu Province, but evidence of other old mines has been found from Aceh in the north to Lampung in the south. ${ }^{13}$

Vegetable products exported from Sumatra included a great variety of tree resins, as well as aromatic woods, canes, and other items. The most valuable of these commodities, certain tree resins, may have come from the mountain forests

suggested. See O. W. Wolters, "A Note on Sungsang Village at the Estuary of the Musi River in Southeastern Sumatra: A Reconsideration of the Historical Geography of the Palembang Region," Indonesia, 27 (April 1979), pp. 33-50.

11. Pineapples and some other plants can be cultivated on such soil. T. Harrisson, "Peat and the Coastal Plain Ecosystem as Controls on Prehistory and Present Human Demography (Southeast Asia)," JMBRAS, 48, 2 (1975), pp. 116-18. In the last few years a new technique of growing rice on such soil has been developed, but there is no evidence that it was practiced in Sumatra or elsewhere in the past.

12. E. C. Mohr, The Soils of Equatorial Regions (Ann Arbor: Edwards, 1944).

13. R. W. van Bemmelen in The Geology of Indonesia, 3 vols. (The Hague: Nijhoff, 1944) summarized the evidence for precolonial gold-mining in Sumatra (vol. 2 , pp. 105-22). He stated that "remains of former native goldmining are numerous and have been found in many places from Atjeh in the north to Benkulen in the south. The extensiveness of the old workings indicates a thorough organization in which thousands and thousands of men must have been employed. It is evident that considerable quantities of gold have been produced" (p. 105). Legends from the Lebong area refer to early mining; P. Hovig, "De Goudertsen van de Lebongstreek (Benkoelen)," Jaarboek van het Mijnwezen in Nederlandsche Oost-Indië, Verhandelingen, 1912, 41, 2, pp. 87-276; and 1914, pp. 98-112. See also Marsden, History of Sumatra, pp. 166, 172-73; A. Tobler, "Djambi-Verslag," Jaarboek van het Mijnwezen 1919. 


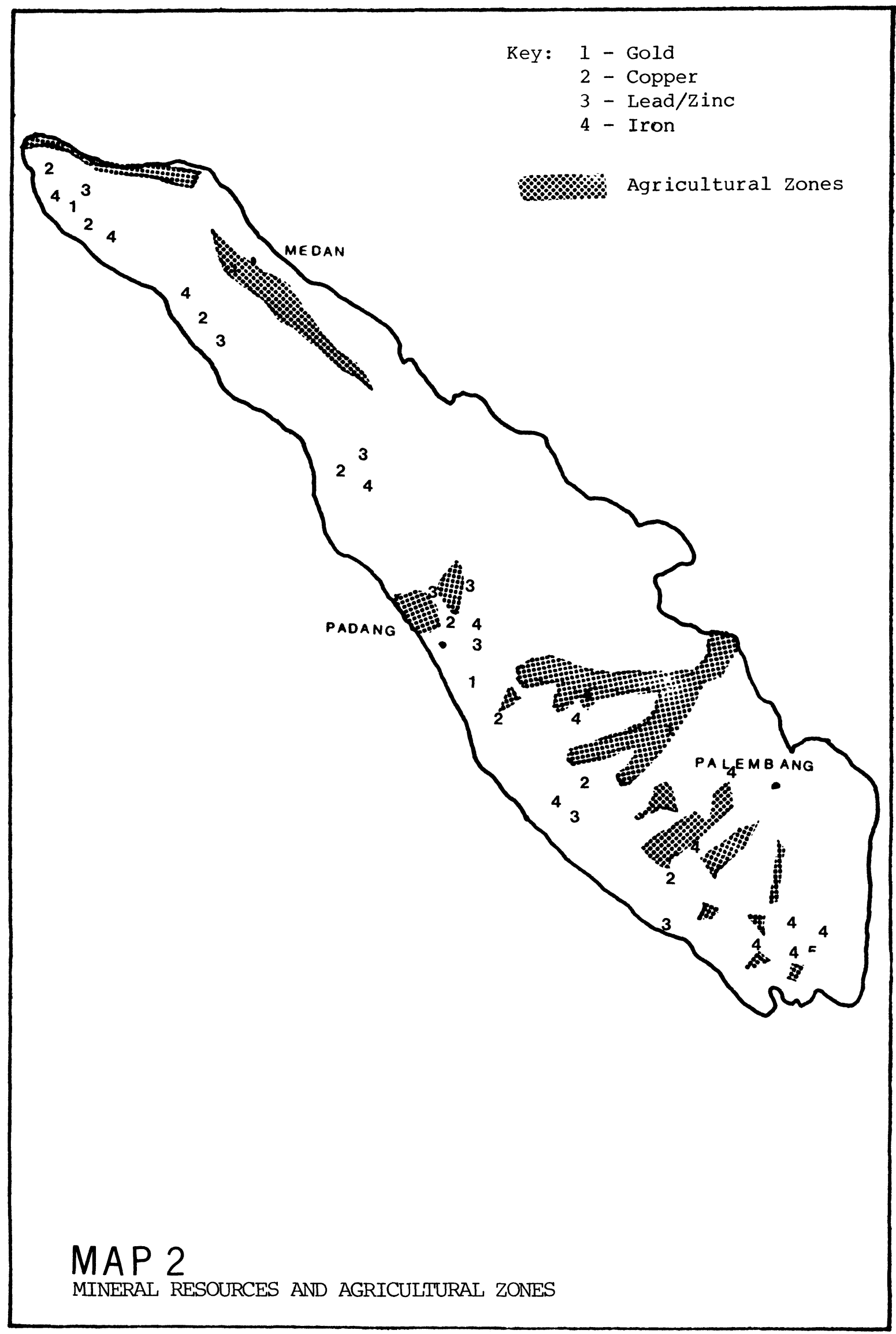


of north Sumatra, and the region of Barus in particular. Animal products included ivory and birds' feathers. ${ }^{14}$

Although the mountains of the north and west probably provided most of Sumatra's early exports, historical sources deal very little with those regions, concentrating instead on the trading centers where outsiders could obtain export commodities. These emporia seem usually to have been located at some distance from the producing zones, the most famous of them lying on Sumatra's east and southeast coastal plain where there is little fertile land. The dearth of information on the producing zones of Sumatra is consistent with the situation regarding other exporting regions of Asia and Africa for, beginning with the very early years of the Christian era, the attention of Western sources was nearly always focused on the trading conditions in the emporia strung along the coasts of the Indian Ocean, including the Malay Peninsula and the Straits of Malacca.

Western descriptions of the trade routes and commercial conditions around the Indian Ocean in the first to second centuries AD appear in two principal works, the Geography of Ptolemy and the Periplus of the Erythraean Sea by an anonymous author. 15 Certain features seem to have been common to all emporia on these trading routes:

A general comparison between the Arabian, East African, and Indian coasttowns designated by the Perip/us as emporion . . . and the oriental coasttowns designated by Ptolemy as emporia . . . shews that with few exceptions, due to local alterations in political or commercial status, . . . by the single word emporion Ptolemy means a nomimon emporion--a legal mart where foreign trade was officially allowed and taxed. . . . in the geographer's descriptions of Indian seas (in other words, as soon as he describes non-Roman but well-known territory) emporion means an authorised sea-coast (not inland) mart in the Orient where non-Roman dues were levied by non-Roman authorities. ${ }^{16}$

This means that, by the early first millennium $A D$, a few ports located in or near the Straits of Malacca were part of a regulated and standardized system of long-distance commerce. We do not know whether any of these emporia were located in Sumatra. Ptolemy mentions "five Baroussai islands," which may be a reference to north Sumatra, but these were places to avoid, not to trade in. ${ }^{17}$ Large ships,

14. Wang Gungwu, "The Nanhai Trade," JMBRAS, 31, 2 (1958), pp. 31-52; P. Wheatley, "Geographical Notes on Some Commodities Involved in Sung Maritime Trade," JMBRAS , 32, 2 (1959); O. W. Wolters, Early Indonesian Commerce (Ithaca: Cornell University Press, 1967).

15. Discussions of these works in relation to Indo-Malaysian historical geography may be found in Wolters, Early Indonesian Commerce; P. Wheatley, The Golden Khersonese (Kuala Lumpur: University of Malaya Press, 1961); W. H. Schoff, The Periplus of the Erythraean Sea (New York: Longman Green, 1912); E. H. Warmington, The Commerce between the Roman Empire and India (Cambridge: Cambridge University Press, 1928); and J. I. Miller, The Spice Trade of the Roman Empire (Oxford: Clarendon, 1969). W. J. van der Meulen ("Suvarṇadvîpa and the Chrysê Chersonêsos," Indonesia, 18 [October 1974], pp. 1-40), provides an interpretation of Ptolemy which differs from that of Wheatley and Wolters.

16. Warmington, Commerce between the Roman Empire and India, p. 107.

17. Wolters, Early Indonesian Commerce, pp. 181-84. Cf. van der Meulen, "Suvarnadvîpa," p. 22. 
called kolandiafonta by the Greeks, sailed to southeast India from Southeast Asia, carrying great quantities of pepper and other commodities sought by the GrecoRoman traders. The home bases of the kolandiafonta were not in India, but somewhere in maritime Southeast Asia. ${ }^{18}$ No solid proof of Sumatran commerce with India during the first two centuries $A D$ has yet emerged. A significant concentration of Roman and western Asian objects has been found at the Oc-eo site in the Mekong Delta. ${ }^{19}$ Within Indonesia itself, however, only some pottery recently discovered in west Java, near Jakarta, ${ }^{20}$ and some Roman coins, reputed to have come from Aceh, indicate that there may have been direct Indonesian contact with these areas.

Chinese sources provide richer data on the trading centers of maritime Southeast Asia, particularly after the fall of the latter Han in AD 220, when official envoys from the Wu and Wei courts traveled to Southeast Asia to procure luxury goods. Soon after this, missions from maritime Southeast Asia began to visit China, and by some date between $A D 250$ and 400 Indonesians were definitely trading with China. ${ }^{21}$ By the early seventh century AD a number of rulers in north and south Sumatra, Java, the Malay Peninsula, and Borneo were sending missions to China, but this number greatly decreased in the later seventh century, probably as the result of a successful attempt by the Sumatran kingdom, Srivijaya, to monopolize the Chinese maritime trade with western Indonesia. ${ }^{22}$ This monopoly was probably maintained with greater or lesser effectiveness until the twelfth century, when the emporia of south China ceased to be the sole legal foci of China's foreign trade, and Chinese travelers began to go abroad in appreciable numbers. ${ }^{23}$

During its ascendancy Srivijaya also maintained regular contact with India and western Asia, and in $A D 671$ the Chinese pilgrim, I Tsing, described it as a highly developed center of Buddhist scholarship. ${ }^{24}$ In 1025 , the Chola dynasty of south

18. On these ships, see A. Christie, "An Obscure Passage from the Periplus," Bulletin, School of Oriental and African Studies, 19, 2 (1957), pp. 345-53. Miller believes these ships were Indonesian, but his evidence is indirect; Miller, Spice Trade, p. 158.

19. L. Malleret, L'archéologie du delta du Mekong, 4 vols. (Paris: Publications de l'École Française d'Extrême Orient, 1959-63).

20. M. J. Walker and S. Santoso, "Romano-Indian Rouletted Pottery in Indonesia," Mankind, 11 (1977), pp. 39-45.

21. Wang Gungwu, "Nanhai Trade"; Wolters, Early Indonesian Commerce. In its ceramic collection, the Museum Pusat in Jakarta possesses a number of Han Dynasty vessels, said to have been found in south Sumatra, but their exact proveniences and the dates of their import to Indonesia are unknown. E. W. van Orsoy de Flines, Guide to the Ceramic Collection (Jakarta: Museum Pusat, 1975).

22. Wolters, Early Indonesian Commerce, pp. 15-16, and note 2 of chapter 1, p. 263.

23. After the accession of the Ming Dynasty in 1368 Srivijayan rulers attempted to revive their monopoly, but by this time east Java had achieved a sufficient degree of control over south Sumatra to prevent a revival of this old system. See 0 . W. Wolters, The Fall of Srivijaya in Malay History (Ithaca: Cornell University Press, 1970), pp. 49-66.

24. On Srivijaya's status as a center of Buddhist learning, see G. Coedès, The Indianized States of Southeast Asia (Honolulu: University of Hawaii Press, 1968), pp. 81-82, 84, 109, 131, 179 and notes. 
India mounted a naval raid on the Straits of Malacca, and an inscription describing the victorious campaign lists a number of conquered ports in the Malay Peninsula and Sumatra. Although the attack's main target was apparently Srivijaya, its motivation is not known. It may have involved commercial affairs, perhaps Srivijayan taxation of shipping in the Straits of Malacca.

With the decline of its monopoly of the China trade, Srivijaya seems to have broken into fragments which probably corresponded at least in part to the old kingdoms which had sent missions to China before the late seventh century. By the end of the thirteenth century, Islam had begun to win acceptance in parts of north Sumatra. Marco Polo, who visited the island in 1292 , wrote that Islam already existed in Perlak, and the gravestone of Sultan Malik al-Saleh, found in Pasai, another port on Sumatra's north coast, is dated $1297 .^{25}$

The vision of Sumatra found in all the external sources is restricted to the emporia where foreign merchants were welcomed. Probably the visitors were not permitted beyond the port precincts, and so were able to provide very little information of use in reconstructing the situation in the interior of Sumatra. As a result, archaeology remains the principal means for discovering what lay behind the facade of the emporion sphere of interaction.

The following summary of the major archaeological discoveries in Sumatra is unavoidably biased by the limited data: until recently, research in Indonesia concentrated on architectural remains, recovery of statuary, and decipherment of inscriptions, to the neglect of ceramic surveys which would enable us to trace the flow of goods in internal exchange networks. Thus, much of the information is incomplete and superficial in the literal sense. Nevertheless, in the context of other historical evidence, a survey of the current archaeological information from the principal Sumatran sites does suggest some hypotheses which may accurately indicate the networks along which the material objects of wealth, and also the invisible forces of political power, may have flowed.

\section{Palembang}

Palembang is regarded by many historians, on the basis both of inscriptions on stones discovered in its environs and of foreign contemporary sources, as having been the center of Srivijaya, a realm famous among merchants and scholars for its wealth and learning between at least $\mathrm{AD} 682$ and $1079 .{ }^{26}$ It would, therefore, seem reasonable to expect significant traces of an ancient site to be found there.

"By far the most extensive text of the empire of Srivijaya" 27 appears on the inscribed stone, formerly called the Telaga Batu but more properly named Sabokingking after the true place of its discovery in a Palembang neighborhood. ${ }^{28}$ This inscription is undated but is believed to be closely contemporary with similar

25. J. P. Moquette, "De eerste vorsten van Samoedra-Pase (Noord Sumatra)," Rapporten van den Oudheidkundige Dienst in Nederlandsche Indië 1973 (1914), pp. 1-12.

26. Wolters, Early Indonesian Commerce; see also Coedès, Indianized States, pp. 32,130 ; and $\mathrm{O}$. W. Wolters, "A Note on the Capital of Srivijaya during the Eleventh Century," in Essays Offered to G. H. Luce, 2 vols. ed. B. Shin, J. Boisselier, and A. B. Griswold (Ascona: Artibus Asiae, 1966), 1, pp. 225-39.

27. J. G. de Casparis, Prasasti Indonesia I/ (Bandung: Masa Baru, 1956), p. 17.

28. E. E. McKinnon and A. C. Milner, "A Letter from Sumatra: A Visit to Some Early Sumatran Historical Sites," Indonesia Circle, 18 (March 1979), p. 11. 
ones from elsewhere in Sumatra which date from the period AD 682-686. The inscription, "precisely the kind one would expect to find in the capital of the empire," 29 is a long oath threatening dire penalties against traitors to the ruler. The oath contains a long list of titles: governors, vassal princes, and twenty-five terms referring to various officials, including clerks, architects, shippers, ${ }^{30}$ merchants, commanders, and slaves. The subjects of the ruler are divided into two classes, lords and commoners.

Two other dated inscriptions found near Palembang, one from Kedukan Bukit (AD 682), and one from Talan Tuo (AD 684), deal with the religious and military activities of Srivijaya's ruler.

Other inscriptions similar in content to that on the Sabokingking stone have been found elsewhere in south Sumatra, including: Karang Berahi, on a tributary of the Batang Hari (undated); Kota Kapur, on the island of Bangka (dated AD 686); and Palas Pasemah (undated). ${ }^{31}$ Several place-names appear in the texts, but although Boechari, de Casparis and others have speculated about the locations they refer to, these have not yet been determined. The scripts of all the texts are very similar, and are derived from a south Indian alphabet (Tamil Grantha). They differ markedly from contemporary inscriptions in Java. ${ }^{32}$ Except for the first few lines, the language of each "oath stone" is old Malay.

The first few (usually four) lines of the oath have not been satisfactorily translated. Obdeijn thought they might be in an Old Minangkabau language, ${ }^{33}$ while Damais found parallels in the Malagasy, Cham, and Javanese languages, and believed they were "sans aucun doute . . d'une langue dont les particularités se retrouvent dans d'autres régions du domaine linguistique nousantarien." ${ }^{34}$ Van Naerssen proposed that the speakers of the unknown tongue may have been Orang Laut, or that it was a lingua franca used between Orang Laut and Malays. ${ }^{35}$ Most recently, Boechari has suggested that the language was a special one used by the Srivijayan rulers. ${ }^{36}$

29. Wolters, Early Indonesian Commerce, p. 209.

30. "One of the few Indonesian terms in this list," which mainly adopts Sanskrit terminology. De Casparis, Prasasti Indonesia II, p. 20. "Datu" is another.

31. The last of these has recently been translated with notes. Boechari, "An Old Malay Inscription of Srivijaya at Palas Pasemah (South Lampung)," in Pra Seminar Sriwijaya, ed. Satyawati Suleiman, R. Mulia, R. P. Soejono, S. Satari, and H. M. Ambary (Jakarta: Pusat Penelitian Purbakala dan Peninggalan Nasional, 1979), pp. $19-42$.

32. K. A. N. Sastri, "Sri Vijaya," Bulletin de l'École Francaise d'Extrême-Orient (henceforth BEFEO), 40, 2 (1940), p. 245.

33. V. Obdeijn, "Volk en taal der oude Maleische rijken in Zuid-Sumatra," TNAC, 60 (1943), pp. 721-23.

34. L. C. Damais, "Études Soumatranaises III. La langue B des inscriptions de Sri Wijaya," BEFEO, 54 (1968), pp. 523-66.

35. F. H. Van Naerssen, "The Economic and Administrative History of Early Indonesia," Handbuch der Orientalistik (1977), p. 34. Several authors have stressed the importance of the Orang Laut ("Sea Nomads") in Sumatran history; Wolters, Early Indonesian Commerce, and more recently L. Andaya, The Kingdom of Johor 1641-1728 (Kuala Lumpur: Oxford University Press, 1975).

36. Boechari, "Old Malay Inscription," p. 25. I have been informed by Dr. Ches- 
Van Naerssen suspects that the Bangka, Jambi, and Palas Pasemah stones were markers of Srivijaya's borders. ${ }^{37}$ The inscriptions, however, do not refer to borders, but to frontier regions (literally frontier roads, or samaryyadapatha), ${ }^{38}$ which may indicate that they were located at important points on communication routes.

The Sejarah Melayu mentions oaths of loyalty taken by the ancestors of the Malays to their first ruler; those who broke the oath would be struck by a curse, ${ }^{39}$ and more recent historians have described how in the early 1700 s Pasemah chiefs swore oaths of fidelity to the Palembang ruler at a tomb on the summit of Bukit Seguntang. ${ }^{40}$ These sources suggest that the oaths commemorated on the stones may have been administered to subordinate chiefs bound by ties of loyalty to the Srivijayan rulers. The chiefs, like those of nineteenth-century Malaya, probably maintained their own bands of armed men, and would have had the crucial role in "neighborhood mobilization" for such tasks as collecting tolls from passing ships, ${ }^{41}$ guarding the coastal regions from attack, and maintaining communication and trade routes between the coasts and highlands. Just such a relationship is portrayed in a number of copper and silver plates engraved with piagem ("decisions"), which were found in south Sumatra. Their contents indicate that the eighteenth century Palembang rulers also held monopoly rights over certain commodities, including pepper, ivory, rhinoceros horn, rattan, coffee, gold, and benzoin, and that these were to be supplied by the highland chiefs under specific administrative arrangements. ${ }^{42}$

The piagem also deal with "Free Frontier Guards" (aturan sindang merdeka) who were Pasemah chiefs protecting Palembang from attack by highland groups. Another matter included in the piagem are regulations for settling personal debts between the people of Pasemah and Palembang. Netscher concluded that these documents implied a considerable amount of commerce between the two regions, and that in the eighteenth century the Pasemah chiefs held a tributary status in regard to the Palembang rulers. ${ }^{43}$ "Free may have meant exempt from taxation but liable

ter Gorman of the University of Pennsylvania Museum that some south Indian inscriptions also contain similarly untranslatable portions. As far as I know, they have never been compared with the Sumatran texts.

37. Van Naerssen, "Economic and Administrative History," p. 34.

38. De Casparis, Prasasti Indonesia II, p. 41.

39. C. C. Brown, Sejarah Melayu or Malay Annals (Kuala Lumpur: Oxford University Press, 1970), p. 16.

40. P. de Roo de la Faille, "Uit den Palembangschen sultanstijd," Feestbundel uitgegaven door het Koninklijk Bataviaasch Genootschap van Kunsten en Wetenschappen bii gelegenheid van zijn 150 jarig bestaan, 1778-1928, 2 vols. (Weltevreden: Kolff, 1929), 2, p. 330.

41. Chau Ju-kua in the thirteenth century described how this was done in the waters off Sumatra; F. Hirth and W. W. Rockhill, Chau Ju-kua (St. Petersburg: Imperial Academy of Science, 1911), p. 63.

42. Notulen van het Bataviaasch Genootschap van Kunsten en Wetenschappen (henceforth $N B G$ ), 1888, pp. 118-21.

43. E. Netscher, "Iets betreffende de verhouding der Pasemah-landen tot de Sulthans van Palembang," Tijdschrift van het Bataviaasch Genootschap (henceforth $T B G), 4$ (1855), pp. 186, 194; see also de la Faille, "Uit den Palembangschen sultanstijd," p. 330 . 
to provision of corvée labor under certain circumstances, as during the Dutch attacks on Palembang in the early 1820s, when highland groups constructed the fort for the Palembang ruler, serving without pay and supplying their own food. ${ }^{44}$

Another south Sumatran custom, termed adat perdagangan serah, regulated traffic in three basic necessities (iron, coarse cloth, and salt) which were sent to the hinterland by the Palembang ruler. ${ }^{45}$ In the early nineteenth century iron tools, gold jewelry, and clothing were manufactured in Palembang, and much of the production was destined for the highlands. ${ }^{46}$ Numerous fragments of iron slag, found, along with brick rubble, at a site slightly upstream from Palembang, indicate that iron-working may be an old occupation in the Palembang area. ${ }^{47}$

Unfortunately no information is available to help determine whether such practices accurately reflect the system in force during the period here termed Classic. The late seventh-century inscriptions discussed above constitute almost the entire known corpus of indigenous Srivijayan literature, and the inventory of other classical-period archaeological finds around Palembang contains only a small number of stone and bronze statues of religious figures, which are as a group "remarkably heterogeneous," 48 and some brick structures, which were destroyed before any could be described or studied. ${ }^{49}$

The Dutch art historian and philologist Bosch, after surveying the Palembang region, summarized his impression in these words:

The Palembang lowlands district belongs to the areas poorest in antiquities from Sumatra. . . Because of our personal experience that the center of the town contained almost no remains that could commemorate the existence of the glorious kingdom of Srivijaya, the question must be raised with emphasis, whether anything is known that would establish the capital of that kingdom in the location of present-day Palembang. ${ }^{50}$

Later research in 1974, which included excavation, met with a similar lack of evidence to support the thesis that Srivijaya was a glorious trading center situated in present-day Palembang. In fact, so few traces of early occupation were uncov-

44. J. L. van Sevenhoven, "Beschrijving van het hoofdplaats Palembang," Verhandelingen van het Bataviaasch Genootschap (henceforth $V B G$ ), 9 (1825), p. 92.

45. De la Faille, "Uit den Palembangschen sultanstijd," p. 348.

46. M. A. Jaspan, "A Note on Palembang in 1832; Urban Manufacturing and the Work Force," BKS, 4, 2 (1975), p. 8.

47. L. C. Westenenk, "Boekit Segoentang en Goenoeng Mahameroe uit de Sedjarah Melajoe," TBC, 68, 1 (1923), p. 224.

48. B. Bronson and J. Wisseman, "Palembang as Sriwijaya, the Lateness of Early Cities in Southern Southeast Asia," Asian Perspectives, 19, 1 (1976), pp. 220-39.

49. F. D. K. Bosch, in "Verslag van een reis door Sumatra," OV (1930), pp. 133-57, describes the Palembang site known as Candi Angsoka as "a very low hill on top of which some deep pits indicate where bricks were dug up by Public Works," and reports that "Bukit Seguntang for years was exploited as a quarry" (pp. 153154). As recently as 1960 , a stupa on Bukit Seguntang may have been taken apart for building material; B. Bronson, Basoeki, M. Sukadi, J. Wisseman, Laporan Penelitian Arkeologi di Sumatra (Lembaga Purbakala dan Peninggalan Nasional--University of Pennsylvania Museum, n.d.), p. 7.

50. Bosch, "Verslag van een reis," p. 155. 
ered that the investigators drew the conclusion that early Srivijaya could not have been located in Palembang or even in the lower Musi basin. ${ }^{51}$

Despite Bosch's statement quoted above, he himself did not believe that historical sources mentioning Srivijaya had necessarily been misinterpreted. Rather he suggested that Srivijaya might have been elsewhere in the Palembang region, perhaps south of the river, opposite the center of the modern city. In support of this speculation he noted that three bronze images, all in an unmistakably central Javanese style, had been discovered in the Komering River, a kilometer upstream from its juncture with the Musi. ${ }^{52}$

More recently, a team from the Pusat $\mathrm{P} 3 \mathrm{~N}$ discovered a number of sherds of tenth-century Chinese ceramics on the banks of the Kedukan River, near Bukit Seguntang. The same team also found sherds of Sung and possibly T'ang-dynasty wares in the Talang Kikim area, two kilometers from Bukit Seguntang. These finds, in the words of the discoverers, "encourage us to insist that the Palembang region should continue to receive the careful attention of archaeologists." 53

Another line of argument has questioned the assumption that the site of the Srivijayan capital would manifest itself to archaeologists as an urban center. Westenenk suggested that the old capital may have contained several separate foci of activity, and that these should be sought further upstream. ${ }^{54}$ Wolters has suggested that Westenenk and Bosch may both be partially correct, and that ceremonial and religious centers in Srivijaya may have been separate from such other areas as trading quarters. ${ }^{55}$ The view that Srivijaya in its early period was not an urban settlement has been expressed most recently by Drs. Hasan $M$. Ambary of the Pusat P3N. ${ }^{56}$ Should this assumption be nearer the truth, it becomes even more vital to search for patterns and links among archaeological sites.

\section{Tanah Abang}

Tanah Abang is located on the lower Lematang River, near its confluence with the Musi and near the point of transition between coastal plain and eastern foothills of the Barisan Mountains, and thus at a strategic junction of transport routes (see Map 1). This site may demonstrate that the region in the hinterland of Palembang did not simply imitate the downstream emporion in its susceptibility to external religious influences. From the village in 1904 a shipment of antiquities, including a lingga, a statue of Brahma, and other Sivaitic religious paraphernalia was sent to Batavia. Although in 1930 Bosch found only three formless heaps of brick at the

51. B. Bronson, "A Lost Kingdom Mislaid: A Short Report on the Search for Srivijaya," Bulletin, Field Museum of Natural History, 46, 4 (1975), pp. 16-20; Bronson and Wisseman, "Palembang as Srivijaya."

52. Bosch, "Verslag van een reis," pp. 155-56.

53. McKinnon and Milner, "Letter from Sumatra," p. 15; E. E. McKinnon, "A Note on the Discovery of Spur-marked Yueh-type Sherds at Bukit Seguntang Palembang," $J M B R A S, 53,2$ (1979), pp. 41-47.

54. Westenenk, "Boekit Segoentang," pp. 224, 226.

55. O. W. Wolters, "Landfall on the Palembang Coast in Medieval Times," Indonesia, 20 (1975), pp. 1, 54.

56. Hasan Muarif Ambary, "Catatan tentang penelitian beberapa situs 'masa' Sriwijaya," in Pra Seminar Sriwijaya, ed. Suleiman et al., pp. 7-17; see also McKinnon and Milner, "Letter from Sumatra," p. 15. 
site, he noted that "most remarkable is the existence of a Sivaitic settlement on the Lematang, where one is permitted to believe that the nearby capital of the mighty Srivijaya should have colored everything in the surrounding area Buddhist." 57 Future research may clarify the question of who established the sanctuaries: were they people from the highlands who found this a convenient point to meet lowlanders, or was the site connected with the Srivijayan capital, perhaps indicating that Srivijaya's rulers did not always strictly confine themselves to the Buddhist religion? In any case, the ruins at Tanah Abang point to a degree of cultural diversity during the Sumatran classic period even among the limited segment of the population that was exposed to direct external influences.

\section{Muara Jambi}

By the late eleventh century historians believe that Palembang may have lost its preeminent position among Sumatran emporia to a settlement located near Muara Jambi further up the east coast on the Batang Hari. ${ }^{58}$ A number of brick structures may once have existed here but nothing now remains of them. The Sultan of Jambi is said to have built his palace of bricks quarried from their ruins. ${ }^{59}$ Only one dated object has been found in the area: a makara (sea monster) statue from the village of Solok Sipin, inscribed with the date AD 1064. ${ }^{60}$ Other makara, three Buddha statues, and a nandi (Siva's bull) statue have also been found on the site. ${ }^{61}$

If historians are correct in believing that a major emporion existed here by the twelfth century, a large deposit of Sung Dynasty porcelain would be expected to mark the spot. Although ceramic remains were discovered during excavations conducted in the area in 1977, however, none could be dated earlier than the fifteenth century. ${ }^{62}$ As insufficient research has yet been carried out, we cannot draw any definite conclusions on the basis of the negative evidence thus far available regarding the earlier existence of an important emporion in the region.

\section{Remains Associated with Adityawarman}

Archaeological and art historical data give an impression that north and south Sumatra followed divergent courses of development in art, language, and writing style, at least after AD 900 . In south Sumatra, influences emanating from Java increasingly permeated the language of inscriptions, architecture, and sculpture after this date, whereas in northern Sumatra such temple complexes as those at Padang Lawas are predominantly the product of an idiosyncratic art style, while some inscriptions from the area begin to foreshadow the later Batak scripts. This is not to imply that no influences from Java reached north Sumatra; in fact numerous examples of such influences could be cited. Rather, the basic thrust of devel-

57. Bosch, "Verslag van een reis," pp. 151-52.

58. Wolters, "Note on the Capital."

59. F. M. Schnitger, Hindoe-Oudheden aan de Batang Hari (Leiden: Brill, 1936), p. 5 .

60. B. Bronson and J. Wisseman, "An Archaeological Survey in Sumatra, 1973," $B K S, 4,1(1974)$, p. 93.

61. Schnitger, Hindoe-Oudheden, p. 5.

62. Ambary, "Catatan tentang penelitian," p. 14. 
opment in north Sumatra elaborated indigenous characteristics, while in south Sumatra Javanese influences were more fundamental.

An inscription from Sungai Langsat, up the Batang Hari River from Muara Jambi, mentions a statue of the Boddhisattva Amoghapasha, which was brought from Java in 1286, and a statue resembling the description was found nearby, at Rambahan. ${ }^{63}$ It is very likely that erection of the statue was connected with the east Javanese conquest of south Sumatra a few years earlier. Probably also associated with these events is the statue of Manjusri, dated 1343, at Candi Jago, east Java, which bears an inscription in Sumatran-style writing and Sanskrit language. This states that a prince named Adityawarman had the statue consecrated. Information from other sources points to the conclusion that Adityawarman was partly of Sumatran descent, possibly the son of the Javanese ruler Krtarajasa and one of two Sumatran princesses captured by the Javanese in $1292 .{ }^{64}$

By 1347 Adityawarman was himself in Sumatra, and inscriptions he erected during the period 1347-71 are numerous in the south central area from the mid-Batang Hari to the Padang highlands. Several of these are written in what is said to be very bad Sanskrit. One commemorates the initiation of Adityawarman as a Bhairawa, a terrible Tantric deity, and a statue found at Sungai Langsat probably represents him in this guise. ${ }^{65}$ Next to one of his inscriptions, at Suroaso in the Padang highlands, is another inscription in a south Indian alphabet, indicating direct south Indian contact with this region. ${ }^{66}$

\section{Muara Takus}

The remains at this site, lying on the upper Kampar River, consist of a complex of brick structures. The major feature is a large stupa-form temple called Candi Miahligai, the date of which is conjectural, estimates ranging between the eighth-ninth centuries ${ }^{67}$ and the twelfth-fourteenth centuries. ${ }^{68}$ The outer layer of the structure, furthermore, envelopes an earlier building which cannot be described or dated. ${ }^{69}$ The style of the stupa has no known parallels except possibly

63. K. A. N. Sastri, History of Sri Vijaya (Madras: University of Madras, 1949), p. 96; Schnitger, Hindoe-Oudheden, p. 9.

64. Sastri, History of Sri Vijaya, p. 100. The use of Sanskrit is also evidence in favor of Adityawarman's Sumatran descent. Of 189 inscriptions from Java listed by Damais ("Études d'épigraphie indonésienne II. Liste des principales inscriptions datées de l'Indonésie," BEFEO, 46,1 [1952], pp. 1-105) as having being written after AD 856, only this and one other used Sanskrit.

65. Schnitger, Hindoe-Oudheden, p. 9; The Archaeology of Hindoo Sumatra (Leiden: Brill, 1937), p. 8; Forgotten Kingdoms in Sumatra (Leiden: Brill, 1964), p. 31 .

66. OV (1912), p. 46. Many inscriptions of Adityawarman have not yet been deciphered.

67. N. J. Krom, Hindoe-Javaansche Geschiedenis (The Hague: Nijhoff, 2nd rev. ed., 1931), p. 133.

68. A. J. Bernet Kempers, Ancient Indonesian Art (Amsterdam: van der Peet, $1959), \mathrm{p}$. 69. Mahaligai is a Tamil word meaning a palace, and is usually applied specifically to the house of a royal lady. R. J. Wilkinson, A Malay-English Dictionary, 2 vols. (Mytilene: Salavopoulos \& Kinderlis, 1932), 2, p. 87.

69. Schnitger, Hindoe-Oudheden, p. 11. The practice of resurfacing temples was 
in Villagaam, Sri Lanka. ${ }^{70}$

An inscribed gold plate found in one of the ruins has been assigned on palaeographic grounds a date of the twelfth century. ${ }^{71}$ No other materials have been discovered that aid in dating when the structures were built. There is no evidence of a large population center in the area, and it has been suggested that the site was in use for only a short time. ${ }^{72}$

Moens once suggested that Muara Takus was the center of Srivijaya, but this hypothesis has not been generally accepted. ${ }^{73}$ Legend connects the construction of the temples with Adityawarman, and suggests that he acquired power over Kampar by marrying his daughter to the local chief. ${ }^{74}$ Muara Takus may have been in some way linked to Padang Lawas, 100 kilometers to the north, via Pasir Pengarajan and Rokan; in support of this are small finds at Manggis and Kotanopan-Pinarik, and a legend of a Batak attack on the site. ${ }^{75}$

\section{Tanjung Medan}

This site is located approximately 75 kilometers northwest of Muara Takus. In 1876 a stupa-form structure still stood here, but in 1930 only brick heaps remained. A gold plate, and a kendi (water goblet) with neck of gold and rim of silver have been reclaimed from the rubble. The plate bore a mandala of eight Boddhisattvas and an inscription of Buddhist formulae in Nagari script, which cannot be older than the twelfth century. ${ }^{76}$ In 1978 a Pusat P3N team visited the site, but their survey of the area revealed no new discoveries beyond a few coarse earthenware sherds and a piece of stoneware. ${ }^{77}$

not uncommon in Sumatra, occurring also at Si Topayan, Si Joreng Belangah, Geding Suro and Sungai Langsat.

70. W. Groeneveldt, in a note appended to G. du Rij van Beest Holle, "Beschrijving van de Hindoe oudheden te Moeara Takoes, XII Kotta Kampar," TBG, 25 (1879), p. 219. The best depiction of the ruins is found in J. W. Ijzerman, "Beschrijving van de Boeddhistische bouwwerken te Moeara Takoes," TBG, 35 (1893), pp. 48-74.

71. Bosch, "Verslag van een reis," p. 149. He speculated that the remains were connected with Krtanagara's Pamalayu expedition of 1275.

72. Bronson and Wisseman, "Archaeological Survey," p. 93; Bronson et al., Laporan Penelitian Arkeologi, pp. 16, 45.

73. J. L. Moens, "Shrivijaya, Java en Kataha," Overdruk TBG, 77 (1937), afl. 3; cf. F. M. Schnitger, "Het ontstaan der rijken aan de Kampar Kanan," TNAG, 57 (1940), p. 390. Schnitger says Moens' hypothesis was based on incorrect archaeological data of Westenenk.

74. Ijzerman, "Boeddhistische bouwwerken," p. 51; Schnitger, "Het onstaan," pp. $399-401$.

75. F. M. Schnitger, Oudheidkundige Vondsten in Padang Lawas (Leiden: Brill, 1936), p. 40 .

76. Bosch, "Verslag van een reis," p. 133; Schnitger, Hindoo Sumatra, p. 14;

Bronson et al., Laporan Penelitian Arkeologi, p. 59.

77. McKinnon and Milner, "Letter from Sumatra," p. 16. 


\section{Padang Lawas}

This region, more correctly called Padang Bolak, ${ }^{78}$ lies on the eastern fringe of the Barisan mountain range, precisely at the point of the easiest pass between east and west coasts in the entire chain. From Gunung Tua and Portibi in the plain (Padang Lawas = "Broad Plain") one can reach Padang Sidempuan and then Sibolga on the west coast. Two large eastflowing rivers, the Barumun and the Panai, spring from sources in the plain. The name "Pannai" appears in the list of places raided by the south Indian Cholas in AD 1025, and also in the fourteenthcentury Javanese poem Nagarakrtagama. ${ }^{79}$ The area of the plain is about 1500 square kilometers, and on it and around its fringes are at least twenty-six ruined brick temples and temple complexes, with numerous associated remains.

The Padang Lawas plain is unlikely to have supported a large sedentary population, despite its favorable location on transport routes, because dry winds from the west coast are able to climb through the pass and sweep across the plain. These westerly winds blow almost constantly during several months each year, creating an unusually barren landscape. ${ }^{80}$ A British traveler in 1849 was struck by the strangeness of the place in an island largely blanketed by tropical rainforest.

We have ascended Gunung Tua and cast our eye downwards from the summit Sipolpal. There we see unrolled a plain without horizon and without variety; an unbounded carpet on which the more or less luxuriant growth of the lalang makes the only diversity, and on which not a single living creature appears to move, where a tree is literally a rarity and has the appearance of stunted dwarfishness, where at a distance of miles, we descry like an oasis in the desert an insignificant thicket, or a small strip of brushwood along the banks of a marsh or stream; where a fell scorching wind blows for months together and from the numerous conflagrations of lalang generally spreads a dull glow, through which the sunlight scarcely forces itself wavering and heavy--in a word where all nature appears to have gone to an eternal sleep. Such is the appearance of Padang Lawas. . . ${ }^{81}$

The gloomy and forbidding aspect of the place is completely in harmony with the nature of the rituals once performed in at least some of the numerous temples on the plain, where ceremonies including human sacrifice were once practiced. The sculptures and inscriptions from some temples indicate that the sites were perhaps funerary monuments and also precincts reserved for devotees of a form of Tantric Buddhism. ${ }^{82}$

The earliest dated object from Padang Lawas is a bronze statue of the Boddhisattva Lokanatha, from Gunung Tua, with an inscription containing the date 1024 . The style of the image is said to be central Javanese, but the inscription contains a Malay word which probably indicates that the statue was made locally. ${ }^{83}$ Other

78. J. B. Neumann, "Het Pane- en Bila-stroomgebied," TNAG, 2, 1 (1855), p. 17.

79. Wolters, Early Indonesian Commerce, p. 193.

80. Mohr, Soils of Equatorial Regions, p. 538; H. Th. Verstappen, A Ceomorphological Reconnaissance of Sumatra and Adjacent Islands (Indonesia) (Groningen: Wolters-Noordhof, 1973), p. 11.

81. T. J. Willer, "The Battas of Mandheling and Pertibi," Journal of the Indian Archipelago and Eastern Asia, 3 (1849), p. 367.

82. Bosch, "Verslag van een reis," pp. 140-45.

83. Ibid., p. 144 . 
inscriptions from the region give dates of $A D 1179,1245$, and $1372 .^{84}$ The 1245 datum comes from an inscription at Porlak Dolok, using a south Indian script. In addition, a bronze female image from the temple named Bahal I may be of south Indian origin, evidence of continued contact between north Sumatra and south India after the Chola raid of 1025 and the Lubo Tua inscription of 1088 [see below, $p$. $60]$.

Elements of Padang Lawas art and architecture have been ascribed to south Indian and to central and east Javanese influences. Some traits, including asymmetric ground plans, are more common in east Javanese temples. But, although the main constituents of temple architecture are "in essence central Javanese, all have undergone more or less intensive changes and transformations on Batak soil. ... ${ }^{85}$ The statuary includes one of the handful of known images of the Tantric deity Heruka, and a lingga on a lotus cushion, associated with Boddhisattvas in the ruins of Si Joreng Belangah. This "Buddhistic lingga" is emblematic of the blending of various external traits with local culture to produce a unique system of symbols. ${ }^{86}$

A survey in 1976 of the environs of the Bara, Pulo, Bahal I, II, and III, Si Pamutung, and Si Topayan temples yielded no indication of early habitation sites. A drainage ditch later dug near the Bahal I temple did, however, unearth a number of coarse earthenware sherds. ${ }^{87}$ These were not of datable types, so it cannot be determined whether they were contemporary with the inscriptions or the statuary. The lack of habitation remains supports the hypothesis that the Padang Lawas complexes were set in a special region reserved for ceremonial activity, and that no large population centers existed in this dry and inhospitable plain. The nexus of communication routes may have passed nearby during the classical period, accounting for the variety of Javanese and Indian-derived traits in the temples and their accoutrements.

Remains of an important ancient emporion may still exist near the mouth of the Panai or of the Barumun River, which spring from the plain, but no research has yet tested this possibility.

Barus

A Chinese source, describing a situation already extant before AD 742 , states that "Srivijaya is a double kingdom and the two parts have separate administrations." ${ }^{88}$ The one part lay in south Sumatra, and the other in a region called lang-p'o-lu-ssu, in north Sumatra, ${ }^{89}$ which produces many of the commodities which were sought by merchants on the Indian Ocean and South China Sea maritime trade route.

In the early sixteenth century and probably earlier, Barus was the main center exporting camphor, one of classical Sumatra's most prized products. As early as

84. Ibid., p. 147; Schnitger, Padang Lawas, p. 13. Schnitger's study includes maps and charts indicating the location of the major temples in the complex.

85. Bosch, "Verslag van een reis," p. 145.

86. Schnitger, Padang Lawas, p. 9.

87. Personal communication from E. E. McKinnon.

88. Wolters, Early Indonesian Commerce, p. 17.

89. Ibid., p. 191. 
AD 851 Barus appeared in an Arabic source under the name of Fansur, which toponym in the nineteenth century referred to the entire area near the river at Barus, and particularly the riverbank opposite the town. ${ }^{90}$ In the early twentieth century there was also a village named Pansur or Patsur upstream from Barus. ${ }^{91}$

Tomé Pires, a Portuguese resident of Malacca in the early sixteenth century, described Barus in favorable terms:

This kingdom is at the head of the trade in these things in all the island of Sumatra, because this is the port of call through which the gold goes, and the silk, benzoin, camphor, in quantities, apothecary's lignaloes, wax, honey, and other things in which this kingdom is more plentiful than any of the others described up to now. ${ }^{92}$

The most prized camphor in Pires' day came from a very limited area on a tributary of the Singkel River. The collectors took their produce to Barus to sell, "lest this camphor be thought something other than the famous kapur Barus." 93

Until very recently, despite the region's historical interest, no archaeological research had been performed there, although chance finds were occasionally reported. In 1872 the Dutch Resident stationed at Barus described four inscribed stones found in the village of Lubo Tua "in the Pansur region." ${ }^{44}$ Three of the stones are in fact fragments of a hexagonal column, destroyed by the last Raja of Barus in 1757,95 which originally bore texts on three faces. The fourth is a separate inscription inscribed on two faces. ${ }^{96}$ The inscription on the hexagonal stone is written in the Tamil language, and states that the stone was erected by a south Indian merchant guild in AD 1088. ${ }^{97}$ The second stone was inscribed with Old Javanese, but, beyond this fact, no information on the text inscribed there has yet been published. ${ }^{98}$

Numerous small finds have also been reported from Barus and environs, but the exact spots of discovery were seldom noted. They include such articles as

90. The Arabic source, the 'Akhbar as'Sin wa'l-Hind, is discussed in Wheatley, The Golden Khersonese, p. 244, and G. Ferrand, Relations de voyages et textes géographiques arabes, persans et turks relatifs à l'Extrême-orient du viiie au $x$ viiie siècles, 2 vols. (Paris: Leroux, 1913), 1, pp. 35-46, 82-88. For the name Pansur, see NBC (1872), pp. 81-82.

91. L. van Vuuren, "De handel van Barus, als oudste haven op Sumatra's Westkust verklaard," TNAG, 25 (1908), p. 1391, and map in J. Tideman, HindoeInvloed in Noord-Batakland, Bataksch Instituut Publication no. 23 (Amsterdam, 1936).

92. A. Cortesão, ed. and trans., The Suma Oriental of Tomé Pires (London: Hakluyt Society, 1944), p. 161.

93. Van Vuuren, "De handel van Barus," p. 1390.

94. Ibid., p. 1393.

95. Tideman, Hindoe-Invloed, p. 32 .

96. $N B G$ (1872), pp. 81-82, and $N B G$ (1873), pp. 80-81. The Kota Kapur and Karang Berahi inscriptions of late seventh century date were also on hexagonal stones.

97. K. A. N. Sastri, "A Tamil Merchant-Guild in Sumatra," TBC, 72 (1932), pp. 314-27.

98. OV (1914), Appendix T, p. 113. 
fragments of earthenware and glazed pottery, ${ }^{99}$ some glass and carnelian beads, ${ }^{100}$ some small stones and gold rings incised with writing, and several small golden bullet-shaped objects with stamped characters. One of the rings bore an inscription in Sanskrit. In fact, a total of seventeen gold rings bearing Sanskrit lettering have been found around Barus, ${ }^{101}$ while another gold ring bore two lines of script which may be Arabic. ${ }^{102}$ Some small stones were also inscribed with Sanskrit, but the work was very poorly done (giving an effect said to be "like children playing"), with one observer suggesting that they were cabbalistic objects of some sort. ${ }^{103}$

The golden bullet-shaped objects found in Barus average about one centimeter in diameter, and are stamped with the Old Javanese character ma. ${ }^{104}$ Similar objects have been found near old gold mines in the Rejang area of southwest Sumatra, ${ }^{105}$ in many parts of Java, ${ }^{106}$ at Gianyar on Bali, ${ }^{107}$ on several islands in the Philippines, ${ }^{108}$ and in south Thailand. ${ }^{109}$ Artifacts of the same type but made of silver have also been found on Java. The art historian, N. J. Krom, believed that these objects were used as money, and that they originated from India, ${ }^{110}$ although he could cite no firm evidence to reinforce his opinion. Another expert on early Southeast Asian money believed that they could have been manufactured at Barus. ${ }^{111}$ It is puzzling that no such objects have been reported from any site in east Sumatra, including Palembang and Jambi, or in Aceh.

A team from the Pusat P3N, led by Drs. Ambary, conducted research in Barus for two weeks in May 1978, and excavated a number of test pits. The team found ceramics at a number of these sites, including $T^{\prime}$ ang and Sung wares at Lubo Tua. No sherds attributable to the Ming period were found there, indicating that occupation had probably ended by the fourteenth century. McKinnon, on a recent visit to Lubo Tua, found there "the oldest assemblage of imported ceramic material that

99. G. J. J. Deutz, "Baros," $T B G, 22$ (1875), pp. 156-63; Tideman, HindoeInvloed, p. 32 .

100. NBC (1872), pp. 81-82.

101. OV (1914), p. 113.

102. W. P. Groeneveldt, Catalogue der Archeologische Verzameling van het Bataviaasch Genootschap van Kunsten en Wetenschappen (Batavia: Albrecht, 1887), p. 292 , no. 1376 , and note 1 .

103. R. H. Th. Friederich, "Over eenige inskriptien op ringen en gesneden steenen (meest afkomstig van Sumatra)," TBG, 7 (1858), pp. 141-46.

104. OV (1914), p. 114; E. Netscher, "Gouden hindoe-munt van Sumatra," TBC, 5 (1856), p. 485; NBG (1879), pp. 109, 144; H. C. Millies, Recherches sur les monnaies des indigènes de l'archipel Indien et de la péninsule Malaie (The Hague: Nijhoff, 1871), pp. 65-68; N. J. Krom, Hindoe-Javaansche Geschiedenis, p. 52.

105. $N B C$ (1911), p. 91.

106. See, for example, $N B G$ (1891), p. 45; NBG (1892), p. 56.

107. OV (1929), p. 18.

108. NBG (1888), pp. 122-23; A. G. Legarda, "Some Notes on the 'Piloncito,"" Barilla , 3, 4 (1976), pp. 192-98.

109. Legarda, "Some Notes," p. 192.

110. Krom, Hindoe-Javaansche Geschiedenis, p. 52.

111. Millies, Recherches sur les monnaies, p. 66. 
I have yet seen in Sumatra." 112 Some sherds, of green-glazed Yueh-type spurmarked bowls, are similar to artifacts McKinnon has described from Bukit Seguntang, in Palembang's environs. At a grave complex at Batu Badan, Drs. Ambary's expedition also discovered the Muslim grave of a woman named Maesurah, dated AD 1206/7, the earliest Muslim grave yet dated in Indonesia. ${ }^{113}$

\section{Kota Cina}

This site is situated near the modern port of Belawan, on Sumatra's northeast coast. John Anderson, a commercial agent, although he seems not to have visited the village, first reported the existence there of "a stone of a very large size, with an inscription upon it, in characters not understood by any of the natives." 114 A search instituted in 1883 did not discover such an object, but did recover a large stone block with a rectangular depression in one face. ${ }^{115}$

The anonymous reporter of 1883 made no other comments regarding Kota Cina, except that no Chinese were living there, a curious circumstance since "Kota Cina" means "fortified Chinese settlement." That he recorded no other observations on the site demonstrates the lack of interest of investigators at that time in potsherds and other habitation refuse ("garbage"). In $1972 \mathrm{Mr}$. McKinnon, then a resident of Medan, learned that numerous fragments of Chinese pottery were to be found scattered over the ground in the village. McKinnon had been charting locations of discoveries of Chinese ceramics in north Sumatra, and has given details on his subsequent research there in several publications. ${ }^{116}$

The site of Kota Cina is the first early emporion and the first early habitation site in Sumatra to be excavated and described. The site is beneath a tongue of land seven kilometers inland from the coast, and only about 1.5 meters above sea level. The remains include at least three complexes of brick ruins (probably former religious sanctuaries), statuary, bone, stone, glass, artifacts of gold, bronze, and iron, and remains of tree resins (damar), an article of trade associated with Sumatra during the classical period. McKinnon also recovered about a ton of potsherds, of which about two-thirds are earthenware, most probably made locally, and the remaining one-third imported porcelain and stoneware, mostly of Chinese manufacture.

112. McKinnon, "Note on the Discovery of Spur-marked Yueh-type Sherds," p. 43.

113. Ambary, "Catatan tentang penelitian," pp. 12-13. It is unfortunate that archaeological research in Aceh has been almost nil, so that no sites from that area appear in this survey. The Dutch occupation of that area of course occurred relatively late.

114. Anderson, Mission to the East Coast of Sumatra, p. 294.

115. NBC (1883), pp. 48-49.

116. E. E. McKinnon, "Kota Tjina, a Site with T'ang and Sung Period Associations: Some Preliminary Notes," BKS, 3, 1 (1973), pp. 46-52; "Research at Kota Cina, a Sung-Yuan Period Trading Site in East Sumatra," Archipel, 14 (1977), pp. 19-32; "Oriental Ceramics Excavated in North Sumatra," Transactions of the Oriental Ceramic Society, 41 (1977), pp. 59-81; E. E. McKinnon and T. L. Sinar, "Kota China, Notes on Further Developments at Kota China," $B K S, 4,1$ (1974), pp. 63-86; A. C. Milner, E. E. McKinnon, and T. L. Sinar, "A Note on Aru and Kota China," Indonesia, 26 (October 1978), pp. 1-42. 
Evidence from dated Chinese and Sinhalese coins, Chinese porcelain, stylistic comparison of statuary, and radiocarbon dates, all support the conclusion that the site was occupied during a period between the twelfth and fourteenth centuries. ${ }^{117}$ As the material can all be assigned dates from the same approximate period, it appears that this occupation was short, perhaps lasting only 100-150 years, but intensive, judging from the density and variety of material deposited there.

of the brick sanctuaries, only foundations remain. The superstructures were probably of timber, a method of construction found at classic period sites in Padang Lawas and in the Merbok Valley, Kedah, Malaysia. Villagers in Kota Cina have found two granite Buddha statues, one of which is very similar to a south Indian image of the thirteenth century. The stone itself is of a type not found locally. ${ }^{118}$ One intact linggam of polished granite and a fragment of another have also been found, and a recent expedition from the Pusat P $3 N$ to the site has discovered another Sivaitic statue. 119 Thus, the people of Kota Cina were probably from at least two religious communities.

Seven coins found on the site originate from Sri Lanka, and were struck during the reign of Sahasa Malla (1200-1202). 120 No other artifacts show definite links to south Asia, although some of the many glass fragments in the debris probably came to rest here via south Indian or Sri Lankan ports. Some of the potsherds also possibly originated from west Asia, perhaps near the Persian Gulf.

Numerous porcelain and stoneware fragments indicate that a thriving commerce was carried on between this site and China. Several thousand copper coins minted in China also have been collected, ${ }^{121}$ and McKinnon excavated a fragment of gold leaf stamped with the Chinese character "gold" from a small structure in one of the brick complexes. ${ }^{122}$ Although it is possible that some other port acted as intermediary in the commerce between Kota Cina and China, there is no evidence of this, and several indications of direct contact. First, no other habitation site in Southeast Asia yet excavated has yielded so much porcelain of such high quality. Second, it is likely that Chinese traders were voyaging to Southeast Asian ports at the time Kota Cina was inhabited. Third, though perhaps less important, is a local legend telling of the arrival of Chinese here in ancient times, when they drove out the original Indian settlers.

Articles of trade exported from here probably included tree resins or damar, pieces of which are found preserved in the ancient habitation remains; gold, which was probably mined in the Bohorok or other nearby areas and worked on the site $;^{123}$

117. McKinnon and Sinar, "Kota China"; McKinnon, "Oriental Ceramics."

118. S. Suleiman and R. Mulia, "Survai Sumatra Utara," Berita Penelitian Arkeologi, 4 (1976), pp. 25, 36; McKinnon, "Kota Tjina," plate 1; McKinnon and Sinar, "Kota China."

119. E. E. McKinnon, personal communication.

120. McKinnon and Sinar, "Kota China."

121. Ibid.

122. Ibid., p. 70 .

123. Evidence for gold-working on the site includes: numerous fragments of quartz, which occurs naturally only in the mountains, and which in Sumatra frequently is associated with gold; fragments of gold leaf and worked gold on the site; round clay objects, probably used as crucibles (one bears a green stain which a local smith identified as the result of borax having been used as a flux during the melt- 
and other vegetable and animal products of the north Sumatran forests and mountains. Kota Cina was probably also linked to other emporia in Southeast Asia, but we cannot yet demonstrate such links.

\section{Deli Hinterland}

In 1977 I accompanied a Pusat P3N team which explored the region inland of Kota Cina, along the Deli River. This survey covered a number of sites, interesting mainly for the information they provided on the economic and political conditions which resulted in the pattern of site distribution we observe today.

Twelve kilometers inland from the river mouth, on the eastern bank of the Deli, lies Kota Jawa. Of this there now remains only a one-meter-high bank, 100 meters long, with a shallow depression on the eastern side, although in 1823 there was a fort of earthen walls, one to one-and-a-fourth miles in circumference, ${ }^{124}$ and in 1918 an embankment three meters high still stood. ${ }^{125}$

Survey of the site turned up sherds of Chinese porcelain of the Sung and Yuan Dynasties, and also of Sawankhalok pottery of possibly the fourteenth century, as well as local earthenware.

At Deli Tua, thirty kilometers inland, there are two more fortifications of the earthen embankment and trench type, on the west bank of the river. The larger of the two earthworks is three hundred meters square, and of a size which would take a great deal of manpower to build. Northern Thai, Sung-Ming porcelain, and earthenware appear at various locations nearby, and on the site itself a single Chinese coin of the period 1111-18 has been found. ${ }^{126}$ A bronze cannon discovered there in 1866 bore a date of 1691 , or possibly $1591 .^{127}$

Kota Jawa and Deli Tua are located at strategic points along the river. At Kota Jawa the land becomes less marshy and more suitable for agriculture than in the flood-prone area downstream. Near Deli Tua, the Deli River becomes unnavigable, and the land begins to rise from the coastal lowland to the Karo Plateau. The latter location is well suited for any strategy aimed at regulating commerce and transport on the highland-lowland route.

In summary, until recently archaeological research in Sumatra tended to concentrade on sites where architecture, sculpture, and/or inscriptions had been found. These sources largely portray the concerns of the small ruling elite of early Suma-

ing of gold); a stone evidently used as a touchstone for analyzing gold purity; molds for producing metal ornaments; and a large quantity of jars of a type perhaps used to transport mercury, used in extracting gold from the ore. J. N. Miksic, "Archaeology, Trade, and Society in Northeast Sumatra" (Ph.D. Thesis, Cornell University, 1979), pp. 206-9.

124. Anderson, Mission to the East Coast of Sumatra, pp. 9, 28, 293-94.

125. W. Schadee, Geschiedenis van Sumatra's Oostkust, 2 vols. (Medan: Instituut van Sumatra's Oostkust, 1918), 2, p. 29 note 1.

126. McKinnon, personal communication.

127. J. Am. van Cats Baron de Raet, "Reize in de Battaklanden in December 1866 en Januarij 1867," TBG, 22 (1875), pp. 164-219; M. Said, Atjeh Sepandiang Abad (Medan: privately printed, 1961), p. 151. 
tran civilization. Studies of the artifacts usually followed the same line of analysis as those of the written texts, in that in each case their focus of concern was to understand complex systems of symbols which are still resisting decipherment. This type of research, as all research on early Sumatran history, is hampered by the ambiguity of the sources and scarcity of material with which to work.

Classical archaeology in Sumatra is still largely involved with evaluating hypotheses drawn from written sources. This is an important task, because, formerly, research on areas thought to be early foci of commerce and religion disregarded some forms of evidence which are now known to be critical to an understanding of the development of Sumatran civilization. Soon, however, archaeologists will need to begin to pursue research along lines dictated not by concern with the accuracy of historical reconstructions, but by the potential for archaeology to create an independent body of knowledge about Sumatra's past development. The picture of Sumatra's past thus created will take some time to become clear, but only then will a proper evaluation of classical Sumatran historiography be possible.

There is reason to believe that ceremonial centers and coastal emporia in Sumatra occupied separate locations, rather than being concentrated in urban or semiurban centers. The inland locations of such sites as Muara Takus and Tanjung Medan may indicate that they served in part to safeguard and regulate intercourse between highland and lowland people, who probably considered themselves as belonging to different ethnic groups. ${ }^{128}$ Markets in areas where exchange takes place between separate and potentially hostile societies are now frequently associated with religious shrines, which act to preserve peace during trading. ${ }^{129}$

It is also possible that these ceremonial centers were royal burial grounds, and therefore separated from settlements of commoners. Records from east Java confirm that rulers' burial places were located outside their residential areas, frequent$1 y$ at great distances. ${ }^{130}$ In central Java the palaces of the rulers may have lain on the north coast, whereas the numerous monumental temples in the south may have constituted a "realm of the dead."131

Ceremonial centers, and also inscriptions, may indicate strategic points on ancient communication and transport routes. Ethnohistorical information such as that cited earlier in this article gives some idea of the form of political and economic relationships between lowland and highland groups, the commodities they exchanged, and the routes and means of transport which were important at the time the reports were written. With these materials as a basis we can map out a methodology which may eventually provide us with a picture of internal Sumatran political and economic institutions, and this picture can then be compared with the one provided by written sources. ${ }^{132}$

128. Bronson et al., Laporan Penelitian Arkeologi, p. 59.

129. Examples are given in F. Benet, "Exploding Markets--the Berber Highlands," in Trade and Market in the Early Empires, ed. K. Polanyi et al. (Chicago: Gateway, 1971), p. 196; J. Boardman, The Greeks Overseas (Harmondsworth: Penguin, $1973)$.

130. W. F. Stutterheim, "Oudheidkundige aanteekeningen," $B K I, 89$ (1932), pp. 278-82.

131. Ibid.; R. Soekmono, "A Geographical Reconstruction of Northeastern Central Java and the Location of Medang," Indonesia, 4 (October 1967), pp. 1-7.

132. I have proposed that the geographical model of dendritic networks is an appro- 
The line of research indicated here will produce an integrated picture, or pattern, of sites, but will probably not permit us to correlate individual sites with places named in historical sources. We can, however, hope to rediscover much of the internal geography of classical-period Sumatra, and thereby pierce the facade presented in the fascinating but tantalizingly incomplete foreign accounts of wealthy and learned Sumatrans dwelling in crowded international emporia which several generations of scholars have done so much to elucidate.

priate part of such a methodology, because the abstract pattern and basic conditions of the model correspond very closely to conditions of transport and trade in classical period Sumatra, and also that the concept of the segmentary state developed by anthropologists can be similarly applied to the problem of early Sumatran political structure; J. N. Miksic, "Historic and Ethnographic Evidence for Dendritic and Segmentary Systems in Java, Sumatra, and Peninsular Malaysia," Paper presented at the Malay World Seminar at Ohio University, Athens, Ohio, May 1979. 